\title{
FILOLOOGIA VABASTAMINE EXCELI KÄEST
}

\section{Kubofuturistliku uusfiloloogia programm}

\author{
TIIT HENNOSTE
}

lustan ühe oma lemmikstseeniga eesti kirjandusest. Oskar Lutsu „Suves”
kohtuvad üle aastate esimest korda Jorh Aadniel Kiir ja Joosep Toots.

„Noh,” ütleb ta [Kiir], „kudas te... sa ka siia saite. Teid... sind... teid pole peale kooliaega enam näha olnud. Olite kõik aeg Venemaal?” (Luts 1987: 23)

Mis siin toimub? Kiir takerdub (Lutsul kolm punkti) ja vahetab kahe lause jooksul neli korda sina ja teie kasutust: te $>s a>$ teid $>$ sind $>$ teid. Mida Luts sellega öelda tahab? Kindlasti näitab takerdumine ja sõnade vaheldamine Kiire segadust, hämmeldust, laiemalt tugevaid emotsioone ootamatu kohtumise puhul. See on niisuguste konstruktsioonide tavaline roll antiikkirjandusest peale. Aga see on vaid pealiskiht. Hämmeldust oleks võinud näidata kuuel muul moel. Miks Luts just sina-teie valikuprobleemi avalikuks teeb? Ja kõige olulisem: miks ta selle just niimoodi avalikuks teeb?

Enne vastamist vaatan linnulennul üle filoloogiast kujunenud keele- ja kirjandusteaduse lahkumineku kesksed suunad. Loo lõpus sõnastan ühe võimaliku kahe distsipliini vahelise koostöövariandi, mis lubab vastata ka toodud küsimustele.

\section{XIX sajandist XX sajandi keskpaigani}

XIX sajandil hoo sisse saanud keeleteadus oli ennekõike võrdlev-ajalooline ja kirjandusteadus ennekõike positivistlik-ajalooline. Keeleteaduse keskmes oli keele muutumist seletavate vankumatute häälikuseaduste otsimine sugulaskeelte ja murrete võrdlemise kaudu. Uurijate eesmärgiks oli selle abil rekonstrueerida keele ajalugu (vt Robins 1990: 180-217). Kirjandusteaduse tuumaks oli arusaam, et tuleb jätta kõrvale metafüüsilised spekulatsioonid ja tegelda mõõdetava, vaadeldava jms osaga kirjandusest. Teost nähti sealjuures kirjaniku isiksuse ja ümbruse peegeldusena. Ehk nagu pani kirja Hippolyte Taine: kirjanduse seletamisel on tähtsad rass, miljöö ja moment. ${ }^{1}$ Kirjandusteaduse olulisim väljund oli kirjanduse ajalugu.

XX sajandi esimene pool tõi mõlemasse distsipliini rea muutusi, millest siinses kontekstis on olulised kaks: liikumine ajaloost kaasaega ning muutumine uurimisobjektikeskseks.

Keeleteaduses tegi Ferdinand de Saussure üliolulise vastanduse diakroonia ja sünkroonia vahele ning edaspidi sai keskseks deskriptiivne sünkroonne

${ }^{1}$ Vt https://en.wikipedia.org/wiki/Hippolyte_Taine (23. VIII 2016). Kirjandusteaduse ajalooülevaadetes käsitletakse XIX sajandi kirjandusuurimist väga vähe. Suhteliselt korralikud on Wikipedia artiklid. 
keeleteadus, mille kõrval keele ajaloo uurimine elas kõrvalharuna (Robins 1990: 218-236). Teiseks eristas Saussure keelt ja kõnet. Keeleteadlaste eesmärgiks sai uurida keelt kui omaette elementide ja vastanduste süsteemi ning jätta kõrvale kõne kui segane juhuslikkuste maailm. Ja kolmandaks suundus keeleteadus samuti osalt Saussure’i mõjul analüütilis-andmekesksest lähenemisest enam teooriakeskseks ja sünteesivaks.

Kirjandusteaduses leiduvad vasted samadele liikumistele (vt Selden jt 2005; Wellek 1991). 1910. aastatel mõjukaks saanud saksa vaimulooline lähenemine (Rudolf Unger, Friedrich Gundolf jt) uuris kirjandust kui aateajalugu. See viis teosest eemale, abstraktsetesse, sünteesivatesse ja ka spekulatiivsetesse arutlustesse ning vajus peagi tagaplaanile. Põhiosa kirjandusteadusest keskendus teosele kui iseseisvale uurimisobjektile. 1915.-1930. aastate vene formalism (Viktor Šklovski, Roman Jakobson, Boris Tomaševski jt) hoidis rangelt analüüsivat joont ja proovis teha kirjanduse vormi uurimisest täppisteadust. Saksa tekstikesksed uurijad kuulutasid: tuleb jätta kõrvale autori elulugu, teksti loomise sotsiaalsed tingimused jms. Uurija esmaseks eesmärgiks on leida teose kui terviku mõte, sõnum, idee. Analüüsi teiseks pooleks on detailne stiili- ja keeleanalüüs, mis ei ole enam eraldiseisev nagu vanas filoloogias, vaid vaatleb vormi teose ideest lähtudes. Selle suuna oluline nimi on Oskar Walzel, aga sellele viitab ka Gustave Lansoni prantsuse tekstianalüüs.

Kõige mõjukamaks tekstikeskseks suunaks sai 1920.-1930. aastatel kujunenud angloameerika uuskriitika, mis tõusis Teise maailmasõja järel akadeemilises uurimises valitsevaks (John Crowe Ransom, Cleanth Brooks, Robert Penn Warren jt). Tekstianalüüsiks kujundas uuskriitika välja lähilugemise (ingl close reading) meetodi: sõnade, kujundite, sümbolite jm teksti komponentide keerukate suhete ja mitmetähenduslikkuste detailse ja peene analüüsi. Ajalooline ja kultuuriline kontekst (miljöö ja moment), autori isik ja tema kavatsused jäid kõrvaliseks. Kirjanduse ajalugu polnud radikaalsemate uuskriitikute arvates üldse võimalik, igal juhul jäi see väljapoole kirjandusteadust. Kirjandus ise oli uuskriitika jaoks eriline allkeel, mille omadused määratleti seda teadus- ja tavakeele omadustele vastandades.

XX sajandi teine pool tõi uued suured muutused. Ennekõike 1960. aastatest alates arenesid välja ja liikusid eraldi teile juba varem vaikselt kujunenud keele- ja kirjandusteaduse „alamsuunad”. Keele poolelt leiame näiteks generatiivse grammatika, tekstilingvistika ja diskursuseanalüüsi, sotsiolingvistika, psühholingvistika, antropoloogilise lingvistika, suhtlusetnograafia ja lingvistilise antropoloogia, semantika ja pragmaatika jne. Kirjanduse poolelt võime tuua näiteks narratoloogia, lingvostilistika, kultuuriuuringud, ökokriitika, erinevad marksistlikud ja feministlikud/sookesksed lähenemised, psühhoanalüüsi, postkolonialismi jm. Tulemuseks oli mõlema teaduse pihustumine, nii et eri „alamsuundade” esindajad tihti enam üksteisest aru ei saanud ning mõnigi kord ka teistest suundadest midagi kuulda ei tahtnud. Ühesõnaga, filoloogia kui tervik on lõplikult lagunenud.

Muuseas, see muutumine puudutab väga vähe eesti kirjandus- ja keeleteadust. Eesti kirjandusuurimine jäi kuni 1990. aastateni valdavalt positivistlikbiograafiliseks. Üksikud hüpped ennekõike saksa keelest laenatud tekstikeskse lähenemise poole jäid vaid katseteks, mis traditsiooni ei loonud. Samuti jäid tõrjutud servaalaks statistilise värsiuurimise katsed jms modernsemad lähenemised. Eesti keeleteaduses valitsesid 1990. aastateni võrdlev-ajalooline keeleajaloo uurimine, keeleajalooga tembitud murdeuurimine ning deskrip- 
tiivne kaasaja kirjakeele uurimine. Hetkeks tuli keeleuurimisse generatiivne grammatika, mis asendus peagi funktsionalistlike lähenemistega. Hüpped tekstilingvistikasse, sotsiolingvistikasse, psühholingvistikasse jms jäid vaid marginaalseteks hetkedeks. ${ }^{2}$

Maailmas said XX sajandi teisel poolel hoo sisse mitu üldisemat suundumust, mis viivad keele- ja kirjandusteaduse üksteisest üha kaugemale. Vaatan neid kolmes rühmas: positivism ja antipositivism, üldkeel ja kirjanduskeel, kvantitatiivne ja kvalitatiivne analüüs.

\section{Positivism ja antipositivism}

Keeleteaduse keskme vallutas empiiriline-kõnelejakeskne uuspositivism, samal ajal kui kirjandusteadus liikus vastassuunas, kohta, mida võiks nimetada teoreetiliseks-lugejakeskseks antipositivismiks.

Keeleteaduse variantide kirevuses on näha üldsuund, mida võib iseloomustada kahe mõistega: funktsionalism ja sotsiaalsus. Selle asemel et lähtuda uurimisel keele struktuurist, lähtutakse funktsioonidest ja püütakse seletada struktuuri funktsioonide kaudu. Selle asemel et uurida keelt kui asja iseeneses, uuritakse keelt tema sotsiaalses toimimises.

Juba 1960. aastal oli Roman Jakobson esitanud oma keelefunktsioonide mudeli (vt Jakobson 2012 [1960]). Mudel toetus kõnesündmuse põhikomponentidele, milleks olid saatja, teade, vastuvõtja, kontekst (teksti referent), kood ja kontakt (füüsiline kanal ning psühholoogiline side saatja ja vastuvõtja vahel). Igaüks neist teguritest tingib keele erineva funktsiooni, mida on seega samuti kuus: kontekstile vastab referentsiaalne funktsioon, saatjale emotiivne (ekspressiivne), vastuvõtjale konatiivne, kontaktile faatiline, koodile metakeeleline ja teatele poeetiline funktsioon, mille loomuseks on keskendumine teatele tema enese pärast. See arusaam vabastas poeetilise keele jäigast sidemest kirjandusega ning lubas vaadata kirjandust ühes reas muude tekstiliikidega. Jakobsoni mudel sai väga kuulsaks, kuid tema kasutamine jäi ennekõike teoreetikute pärisosaks.

Ühtlasi tõstsid funktsionalistlik-sotsiaalsed lähenemised esiplaanile keelekasutuse varieerumise, fakti, et igas keeles on hulk allkeeli (ingl variety). Varieerumine omakorda vajab seletamist. Laialt võttes kujunes välja kaks seletuste rühma, mis mõlemad lähtusid sellest, et keelelisi valikuid mõjutavad keelevälised tegurid.

Ühes rühmas said seletajaks kõneleja/kirjutaja omadused ning nende suhted kuulaja/lugeja vastavate omadustega. Markantseim suund on siin sotsiolingvistika, mis leidis, et inimese keeleliste valikute olulisimaks määrajaks on sotsiaalne rühm või suhtlusvõrgustik, millesse ta kuulub. Konkreetsemate mõjuritena toodi välja keelekasutajate haridus, sotsiaalne päritolu, elukoht, sugulased, sõbrad, naabrid, töökaaslased. Selle lähenemise keskne mõiste on dialekt (vt ülevaatlikult Chambers, Trudgill 1998).

Teises rühmas võeti seletamise aluseks erinevad keelekasutuse situatsioonid. Eri autorid lõid erinevaid mudeleid ja leidsid erinevaid keelevalikute

${ }^{2}$ Vt kirjandusuurimise ajaloo kohta Tiit Hennoste artiklisarja „Hüpped modernismi poole II. 20. sajandi eesti kirjandusteadus Euroopa kirjandusteaduse taustal” Vikerkaares (2005-2012) ning keeleteaduse ajaloo kohta Reet Kasiku raamatut „Stahli mantlipärijad” (2011). 
situatiivseid mõjureid (vt ülevaatlikult Biber, Conrad 2009). Olgu siinkohal toodud vaid olulisemad mõjuripaarid: suuline suhtlus vs. kirjalik suhtlus, silmast silma suhtlus vs. vahendatud suhtlus, dialoog vs. monoloog, argine suhtlus vs. institutsionaalne suhtlus, spontaanne vs. teksti redigeerimist võimaldav olukord, informeerimine vs. suhtlemine ise (ingl small talk või eesti lobisemine) kui suhtluse põhieesmärk. Kokkuvõttes sai selle lähenemise põhimõisteks register, keelekasutuse situatsioonikeskne variant. Olulisimad registrid on kirjakeel, suuline keel, argikeel, kirjanduskeel, teaduskeel, asjaajamiskeel, netikeel (ingl netspeak) jm.

Kirjandusteadus liigub teisiti. Ka mõned kirjandusteaduse suunad on empiirilised-objektiivsed, näiteks lingvostilistika. Ka mõne kirjandusteaduse suuna keskmes on kirjanduse ja ühiskonna suhted, näiteks sookesksed uuringud või postkolonialism. Aga erinevused on olulisemad.

Kõigepealt, XIX sajandi kirjandusuurimine oli otsinud teksti erijoonte võtit autorist ja XX sajandi esimene pool tekstist endast. Sajandi teisel poolel kujunesid välja lugejakesksed suunad. Need arendasid liini autorikesksustekstikesksus-lugejakesksus loogilise lõpuni ja otsisid vastuseid küsimusele, milline on lugeja osa teksti või tema tähenduse loomisel. Selle suundumuse kujundlikuks tipphetkeks võib pidada aastat 1968, kui Roland Barthes kuulutas autori kui teksti tähenduse jumaliku looja surnuks (Barthes 1998).

Ja kõige olulisem, kirjandusteaduse keskme vallutasid postmodernism, poststrukturalism, dekonstruktsioon jms üksteisest raskelt eristatavad suunad (ilunimedeks Jacques Derrida, Roland Barthes, Edward Said ja teised postkolonialistid, Michel Foucault, Gilles Deleuze, Félix Guattari, Jean Baudrillard, Yale'i koolkond USA-s jne). Selle lähenemise tulemuseks oli eklektiline kooslus nimega „postmodernne (kriitiline) teooria”, mõnikord lihtsalt suure tähega Teooria (vt eesti keeles Malpas, Wake 2015).

See Teooria pole lihtsalt empiiriast eemaldumine. See on nähtus, millega konkreetse teksti juures polegi suuremat teha. Suure osa sellest moodustavad aforistlikud ja hämaravõitu laused, uued sõnad ja mõisted, mis on mõnigi kord inspireerivad, kuid tekstitegelikkusega vaid hapralt seotud. Teoorias peaaegu puuduvad nn kesktaseme mõisted, mille abil saaks üldisi lauseid konkreetse tekstiga siduda. Lisaks seavad post-mõtlejad objektiivset teadmist otsiva strukturalistliku mõtlemisviisi põhimõtteliselt kahtluse alla. Nende jaoks ei ole tekstist väljaspool mitte midagi, kõik on vaid keelesisene lõputu mäng. Tekst on üksnes juhuslik ja ebaoluline kuju, mille kirjatähed on võtnud. Ja varem otsitud teksti terviklikkuse idee asendub arusaamaga, et tekst on üksteisega vastuolus olevate lugemisviiside pundar. Seega pole vaja seda ideed ka otsida, vaid lihtsalt teksti nautida. ${ }^{3}$

\footnotetext{
${ }^{3}$ Muuseas, empiirilisemad kirjandusuurijad on suhtunud Teooriasse ja selle tegijatesse väga kriitiliselt ja ka irooniliselt. Ilunäiteks sobib siin üks kuulsamaid postkolonialismi teoreetikuid, Harvardi ülikooli professor Homi K. Bhabha. See mees on saanud muuhulgas eriauhinna eriti halva kirjutusstiili eest ning kuulsa avangardiuurija, Stanfordi ülikooli emeriitprofessori Marjorie Perloffi arvates pole tal lugejatele mitte midagi öelda. Vt: https:// en.wikipedia.org/wiki/Homi_K._Bhabha (11. IV 2016).
} 


\section{Üldkeel ja kirjanduskeel}

Kirjandus- ja keeleteadust ühendab keel ja selle kasutus kui uurimisobjekt. Kirjandusteadus keskendus XX sajandi keskpaigast alates tugevalt avangardismile/modernismile ja unustas realismi ning XIX sajandi suundumusi edasi arendavad kirjanikud. See tähendas ka tegelemist ennekõike modernismile omaste keeleliste konstruktsioonidega.

XX sajandi alguseni oli ilukirjandusliku proosa keel üldkeelele üsna lähedane nähtus. Kirjakeelse autoriteksti kõrval leidus seal otseses kõnes argikeelt, slängi, murdeid jms. XIX sajandi keskses proosavoolus realismis taotleti lausa programmiliselt „loomulikku” keelt.

Murrangu tõid XX sajandi alguse avangard ja proosamodernism. Futurism ja sürrealism võtsid eesmärgiks keele lammutamise, kuid nende lammutustöö piirdus ennekõike luulekeelega ja programmtekstides leiduvate üleskutsetega „sõna vabastamiseks". Proosas tõi murrangu modernistide seltskond eesotsas James Joyce'iga. ${ }^{4}$ Eri liikumiste ja autorite programmilised ideekuulutused olid erinevad, tegelikud tulemused aga keele seisukohast üsna ühesugused.

Uuenenud proosa ja luule keelekasutus ei vastanud enam kirjakeele normingutele ega olnud ka „loomulik” kirjalik keel. Klassikalise lause asemele asusid mõnikord süntaktilistest ja morfoloogilistest piirangutest vabastatud sõnade read, mõnikord grammatiliselt puudulikud konstruktsioonid, mõnikord lausungid, mis sisaldavad katkestusi, parandusi, lisandusi jms ning meenutavad spontaanse suulise keele ehitusüksusi. „Korraliku” keele seisukohast olid need lihtsalt vead. Aga vigade parandamise asemel kuulutasid avangardistid, ennekõike futuristid ja sürrealistid, vigade innovaatilist väärtust. Uue ideaali võib kokku võtta vene futuristi Igor Terentjevi (2014: 103) programmilise lausega aastast 1919: „Kui ei ole viga, ei ole midagi.”

Keeleteaduse teoreetiline tuum jäi kirjanduskeele avangardistlikust pöördest puutumata. Avangardismi/modernismi toodud kirjanduslausete süntaktilistest joontest grammatikud ei kõnele, kuigi kirjandusteosed on keeleteaduses alati olnud olulised analüüsinäidete otsimise kohad.

Üks hiljutine isikliku kogemuse näide. Mul tuli teha uue eesti keele kirjeldava grammatika töörühma seminaris sissejuhatus lause defineerimise probleemi. Keeleteaduses kõneldakse kahest lausest. Ortograafiline lause on teksti ortograafiline ehitusüksus, lihtsalt öeldes algussuurtähe ja lõpumärkide vahel paiknev teksti osa. Aga mida teha, kui ilukirjanduses jäetakse kirjavahemärgid lihtsalt ära ja lause piirid hajuvad uttu? Grammatiline lause on grammatiliste seoste kooslus, mis kannab terviklikku mõtet. Aga mida teha sellise lausega nagu Erni Hiire „oi on evad evad-evad K K K” (1975: 39)? Selles on kindlasti arusaadav ja terviklik mõte, kuid sõnad on löödud puruks ning grammatilised seosed selle kaudu lõhutud. Või mida teha Toomas Liivi lausega „Katkematutes vahtralehtedes karjub kattuvalt ja katkematu” (2003: 101)? Mis on siin seotud ja kuidas? Ja mis on selle lause "terviklik mõte”?

Kokkuvõttes jõudsin enda jaoks üllatava tõdemuseni. Lause määratlemisel lähtub keeleteadus siiamaani vaikimisi neljast implitsiitsest piirajast: neutraalstiil, otsetähenduslikkus (mis väldib metafoore jms), reeglitele vastavus ja redigeeritus (mittespontaansus).

${ }^{4}$ Vt minu arusaamu ja taustaviiteid Hennoste 2016: 200-203, 218-220, 240-241, 266267. 


\section{Kvantitatiivne keeleteadus ja kvalitatiivne kirjandusteadus ning vastupidi}

Keele- ja kirjandusteadus liikusid eri suundades ka üldise uurimismeetodi valimisel.

Keeleteadus muutus 1960. aastatest alates üha kvantitatiivsemaks. Olulisim mõjur oli siin uurimisandmete teisenemine. Seni domineerinud introspektsioon ja keelejuhtidelt kogutud või kirja pandud tekstidest leitud suhteliselt juhuslikud andmed asendusid arvutipõhiste suurte tekstipankadega. Kuulsaks said esimesed korpuslingvistid. Britt Randolph Quirk algatas aastal 1959 suurkorpuse „Survey of English Usage”. 1972. aastal avaldas ta koos kaasteelistega selle andmetele toetudes „A Grammar of Contemporary English” ning 1985. aastal selle uuendatud versiooni „A Comprehensive Grammar of English Language”. Mõlemad grammatikad on seniajani alusteosed, millest lähtutakse. Ja Quirkist endast sai peer.

Aga tõeline kvantitatiivne pööre tuli siis, kui ameerika uurija Douglas Biber hakkas 1980. aastate teisel poolel analüüsima tekstimassiive arvutiprogrammide ja matemaatiliste meetodite abil palju keerukamalt kui seni (vt Biber 1988). Biberi töörühmalt ilmus aastal 1999 „The Longman Grammar of Spoken and Written English", milles esmakordselt toodi grammatikas välja statistilised ülevaated eri keeleliste konstruktsioonide kasutusest olulistes registrites (suuline vestlus, ilukirjandus, ajakirjandus, teadus).

Sisuliselt said korpusest lähtumine ja kvantitatiivne analüüs keeleteaduses normiks. Osa lingviste ütleb otse: lingvistikas on teadust just nii palju, kui seal on matemaatikat. Arvutid ja programmid muutusid üha võimekamaks ja samas kasutajale üha lihtsamaks. Nii on keeleteadusest saanud üha enam Exceli ikoonide vajutamise kunst. Uusima aja kuumaks märksõnaks on aga tõusnud digilingvistika või digihumanitaaria, mille eesmärgiks on uue nime all kokku sulatada erinevad digitaalsed tehnoloogiad ja humanitaarteadused. ${ }^{5}$

Põhiosa empiirilisest kirjandusteadusest jäi kvalitatiivseks, kuigi kvantitatiivseid meetodeid oli kirjanduse uurimiseks kasutatud juba XIX sajandil. Aga see oli marginaalne suund, mis keskendus ennekõike teose tehnilistele aspektidele, eriti värsivormile.

1990. aastatest alates hakkas kirjandusteadus muutuma. Kõigepealt, Teooria vajus tagaplaanile ja postmodernism ei huvitanud enam suurt kedagi. Teiseks, kvantitatiivne lähenemine hakkas vallutama ka kirjandusteaduses uusi alasid, taustal kirjanduskorpuste areng. Alguses olid uurimise all pigem klassikalised lingvistilised probleemid, nt eri temaatilistesse peredesse kuuluv sõnavara, lausepikkuse võrdlused, tekstide seosed sarnasuste alusel, aga ka näiteks autorsuse tuvastamine. Uuel sajandil asusid aga mõned kirjandusuurijad kuulutama programmiliselt uut aega.

Keskne kuju on siin Stanfordi ülikooli professor Franco Moretti. Tema ideede idud lähevad tagasi 1990. aastate algusesse, aga said hoo sisse 2000. aastatel, kui Morettist sai kuulsaim eestkõneleja suunale, mis kuulutab, et kirjanduse uurimiseks pole tekste lugeda vaja. Lähilugemise asemele asugu kauglugemine (ingl distant reading) ning üksiktekstide kvalitatiivse analüüsi

${ }^{5}$ Vt nt David L. Hooveri sissevaadet „Quantitative Analysis and Literary Studies”: http:// digitalhumanities.org/companion/view?docId=blackwell/9781405148641/9781405148641. xml\&chunk.id=ss1-6-9\&toc.id=0\&brand =9781405148641_brand (12. IV 2016). 
asemele suurte teosekorpuste kvantitatiivne analüüs arvutite abiga (Moretti 2013). Franco Moretti pole üksi, tema kõrval seisavad teised, näiteks Matthew Jockers, kes rõhutab mikroanalüüsi asemel makroanalüüsi (ingl macroanalysis; Jockers 2013).

Sealjuures on Moretti esmapilgul imelikuna mõjuva idee taga oluline tähelepanek. Kvalitatiivne analüüs tegeleb alati üksnes väheste valitud teostega, eelistades uuenduslikke või tippteoseid. Aga mis toimus kirjanduses tegelikult? Millest kõnelevad need tuhanded teosed, mida lähilugejad ei jõua ega suuda vaadata või ei vaevugi vaatama? Alles nende arvestamine näitab meile kirjanduse tõelist palet.

Tegelikult pole selles mitte midagi uut. Just samad mõtted juhtisid keeleteaduses suurte korpuste loojaid, kes leidsid arvutite abiga selliseid keelejooni, mis ei olnud varem uurijate pilgu ette sattunud. Kindlasti toob massiivne andmeanalüüs kirjandusteostes välja aspekte, mida uurijad pole kunagi tähele pannud. ${ }^{6}$

Teisalt saame välja tuua ka keeleteaduse teatud muutused. Kvantitatiivse lähenemise kõrval on viimastel kümnenditel saanud üha suuremat tähelepanu kvalitatiivne analüüs. See seostub väga tugevalt suulise spontaanse dialoogi tõusuga oluliseks analüüsiobjektiks ning selle levikut on märgatavalt toetanud kirjaliku spontaanse dialoogilise netisuhtluse väljakujunemine.

Suulist keelt tõlgendati läbi aegade kui midagi kaootilist või lihtsalt vigast. Tegelikult põhines selline arusaam ainult arvamustel (mis ei ole osade „tõsiste” lingvistide hulgas tänini kadunud). Tegelikku suulist keelt sai hakata uurima alles siis, kui tulid korralikud salvestusseadmed. Erinevate uurimissuundade algused lähevad tagasi 1970. aastatesse, kuid suurema hoo said need 1990. aastatel.

Suulise keelekasutuse uurimine tõi kaasa uutmoodi arusaama keelest ja keeleteaduse kesksest uurimisobjektist, lausest. Kõneldes luuakse lause ühel ajal tema väljaütlemisega. Teisisõnu, lauses saavad kokku kõneleja soovitav tulemus ja lause tootmise protsess (mis kirjas jääb pea alati lugeja eest varjatuks). Selles pole midagi eriti ootamatut ega uut. Uus oli aga leidus, et lause tegemise protsess pole mitte juhuslik ega kaootiline, nagu seni üldiselt arvatud. Vastupidi, vigade parandamine, sõnade asendamine, lausetele „vales kohas" sõnade juurde lisamine jms on tegevused, millel on omad funktsioonid, omad struktuurid ja omad ehitusnormid (vt eneseparanduse kohta Hennoste 2014). Teisisõnu, nad on just samamoodi grammatika osad nagu alus ja öeldis.

Teisalt tõi uurimine ka välja, et selliste nähtuste analüüsimiseks ei sobi kvantitatiivsed meetodid. Neid nähtusi lubab leida ja analüüsida vaid kvalitatiivne mikroanalüüs. Olulisimaks suulise suhtluse mikroanalüüsi meetodiks sai 1970. aastatel kujunenud vestlusanalüüs, millele toetus 1990. aastate lõpust alates kujunenud suhtluslingvistika. Vestlusanalüüs on tegelikult suulise suhtluse analüüs, mille eesmärgiks on leida suhtluse korduvad mustrid ja suhtlemist juhtivad normid. Suhtluslingvistika on keele uurimine, mis kasutab meetodina vestlusanalüüsi.

${ }^{6}$ Minu ülikooliajal tegi poeetikauurija Jaak Põldmäe XIX sajandi lõpu värsside analüüsi ja kasutas arvuti asetäitjana muuhulgas oma üliõpilasi. Me kõik pidime analüüsima mõnda värsikogu ja selle kohta statistikat tegema. 


\section{Läheme uuele katsele}

Alustame uuesti eelnevas jutus toodud märksõnadest. Minu arust on katse luua uuesti filoloogia kui suur süntees määratud nurjumisele, sest pihustunud maailma ei saa uuesti tervikuks liita. Küll aga on mõtet kõnelda sellest, kus kirjanduse ja keele uurimine kokku võiks saada. Siin pakun ühe võimaluse.

Esimene asi on leida kokkusaamise lähtepunkt. Minu arvates saab selleks olla ainult tegelik tekst kui uurimisobjekt. Tekstid on ainus reaalsus, mis uurijale on antud. Kõik muu on tuletis.

Küsimus tekstist toob kaasa küsimuse allkeelest. Kirjandus on alati olnud individuaalne nähtus, milles autorid proovivad luua võimalikult personaalset keelt või stiili. Kas ja kuidas seda panna allkeelte mudelisse? Allkeeled on eri laiusega nähtused. Nende kitsamas otsas on ühe inimese idiolekt ja laiemas otsas näiteks kogu eesti kirjakeel. Minu jaoks ei ole kirjanduskeel teistega võrdne allkeel, nagu vaatab seda näiteks Biberi mudel. Ega ole ka eraldi allkeel, mida eristab poeetilise funktsiooni prevaleerimine nagu Jakobsoni mudelis.

Igal inimesel on oma idiolekt, mis mingil määral erineb teiste omast. Siiski on eri idiolektide ühisosad väga suured, vastasel juhul oleks vähegi sujuv igapäevane suhtlemine võimatu. Ainult kirjandustekst on XX sajandil programmiliselt individuaalsust taotlev ja väärtustav tekst. Teiselt poolt on kirjanduskeel minu jaoks sünteetiline allkeel, mis seob kokku teised allkeeled. Kirjandustekst ühendab suulise ja kirjaliku keele, erinevad sotsiaalsed ja maa-alased keelevariandid, kirjakeele ja slängi, monoloogi- ja dialoogikeele, tänapäeval ka netikeele ja trükikeele jne. Võime öelda, et kirjandustekstis realiseerub allkeelte sünteesi ja autori idiolekti omavaheline dialoog.

Teiseks on oluline valida üldine lähenemine, kas kvalitatiivne või kvantitatiivne. Kui kasutada mõlemaid, siis tuleb küsida, milline on kummagi roll. Suured tekstikorpused, Excelid ja kvantitatiivsed meetodid on kindlasti vajalikud. Aga ma ei ole nõus Morettiga ega nende keeleuurijatega, kes leiavad, et kvantitatiivne analüüs peab asendama kvalitatiivse analüüsi. Ma ei arva, et kirjanduse või keele uurimine leiab tõe kvantitatiivse analüüsi kaudu. Ma arvan, et kvantitatiivsest analüüsist enamasti ei piisa ja mõnikord on ta lausa kasutamatu. Miks?

Kvantitatiivne lähenemine tähendab mõõdetavust. See omakorda eeldab lahterdamist. Kui nähtusi lahtritesse panna ei saa, siis uurida ei saa. Lahterdamine nõuab lahterdatava nähtuse täpseid määratlusi, mis välistab udused perifeeriad ja kattuvused eri kategooriate vahel. (Muuseas, suurte korpustega tegelenud lingvistid on sellest probleemist tihti lihtsalt üle saanud. Kui valitud tasandil täpselt liigitada ei saa, siis tehakse laiem ja üldisem liigitus, mida saab teha. Tulemuseks on tihti nii hõre reha, et sellega ei kraabi suurt midagi kokku.)

Kirjandus on alati liikunud piiril. Seal ei kehti defineerimisel pea kunagi vajalikud ja piisavad tunnused. Heal juhul leidub piisavalt selge tsenter ja hajuv perifeeria, enamasti aga leiame nähtuste vahel udused ludwigwittgensteinlikud perekonnasuhted. Kui panna selline hämarus lahtritesse ja teha kvantitatiivsed tehted, siis saame tulemuseks vead. Statistilisel analüüsil viga teadupärast suureneb, mitte ei vähene ega kao. 
See tõstab üles ühe vana küsimuse. Hämarus on olemas igas allkeeles, ka nendes, mis taotlevad maksimaalset täpsust, nagu juura või reaalteadused. On alati vaieldud, kas hämarad alad tekivad selle tõttu, et uurija pole suutnud piiri üles leida, või on nad keelele olemuslikud. Mina olen kindlalt viimast meelt. Lisaks, asi pole ainult kirjanduskeele hämaruses. Keel, mis lubab kõike ainult täpselt väljendada, on igasuguseks sotsiaalseks suhtluseks kõlbmatu. Keel kui niisugune peab olemuslikult võimaldama kasutajal olla hämar. Mõnikord on inimesel vaja väljenduda täpselt. Selleks on tal näiteks sada sõna lume kohta. Aga sama vajalik on ebamäärasus. On olukordi, kus ütleja ei saa täpselt väljenduda, sest ta ei tea, milline sajast lumest hetkel väljas on. Ja veel olulisem on see, et mõnikord keelekasutaja tahabki jätta ebaselgeks, milline lumi väljas on. See jätab tõlgendamise võimalused kuulajale ning lubab tal valida endale sobiva tõlgenduse. Hämarus nõuab uurijalt kvalitatiivset lähenemist.

Miks on siis üldse vajalik kvantitatiivne analüüs? Kolmel põhjusel. Kõigepealt, kvantitatiivne analüüs saab olla lähtekoht, esimene reha. Selle abil saab selekteerida välja aredate piiridega kooslused, nii sagedased kui ka haruldased. Teiseks on kvantitatiivne analüüs vajalik selleks, et kvalitatiivsel analüüsil leitud mustrite levik üle vaadata ja pääseda sellega välja vaid üksikute tekstide analüüsi nõiaringist. Ja kolmandaks võib kvantitatiivne analüüs olla ,järelabi”. Seda on vaja seal, kus kvalitatiivne analüüs annab tulemused, mida lugeja „ei usu”. Keeleuurijatele on hästi tuntud fenomen, milles inimene kuulutab, et „mina niimoodi ei räägi” (eesti viimase aja kauneimad karjatused seostuvad sõnavormiga $v \ddot{a})$. Uurija kehitab õlgu, avab korpuse ja näitab statistikat.

Seega jõuame olukorrani, kus tuleb postuleerida: kvantitatiivne analüüs seal, kus lahterdamine on võimalik, kvalitatiivne analüüs seal, kus see võimalik ei ole. Aga kokkuvõttes on kvantitatiivne lähenemine siiski abivahend. Päris filoloogia algab sealt, kus statistika lõpetab. Exceli klahvidel mängimise asemel tuleb kirjandusteadusel ja keeleteadusel leida ühised kvalitatiivsed lähenemised, mis lubavad teha keeleteaduslike meetoditega kirjandustekstide täppisanalüüsi.

\section{Vestlusanalüüs kui suulise dialoogi uurimise meetod}

Tekstikesksus toob tahes-tahtmata kaasa kaks metoodilist valikut. Esmalt, konkreetne tekst kui uurimisobjekt on alati sünkrooniline nähtus. Diakrooniliseks saab minna alles siis, kui on tehtud piisavas koguses sünkroonilisi analüüse. Teiseks, teksti analüüsimine on e m pi ir il in e tegevus, milleks on vajalik mingi teoreetiline mudel või meetod. Ainult milline meetod? Minu pakkumine on lihtne. Kirjandusteose kvalitatiivseks analüüsiks sobib kasutada vestlus an alüüsi, mis on suulise dialoogi uurimise meetod. Millised on vestlusanalüüsi olulised aluspõhimõtted (vt pikemalt Sidnell 2013)?

Esimene. Keel oma esmases kasutuses on dialoogilise argisuhtluse vahend ning tema struktuur on kujundatud/kujunenud vastavalt sellele. Dialoogi eesmärk ei ole toota lauseid või kõnevoore, vaid sooritada keele (ja häälitsuste, pilkude, žestide jm) abil erinevaid suhtlustegevusi (ingl social action). Vestlusanalüüsis ongi keskne uuritav nähtus suhtlustegevus ehk see, mida kõneleja keele abiga teeb (küsib, vastab, imestab, jutustab lugu, mõnitab, 
haliseb jne). Eelnevast loendist on näha, et suhtlustegevused on analoogilised filosoofiast tuntud kõneaktidega, kuid konkreetsed tegevused on oluliselt kitsamad kui kõneaktid ning leitavad empiirilise uurimise abil, kusjuures nende lõplikku loendit pole võimalikki esitada.

Teine. Dialoog sünnib alati partnerite mikrokoostöös. Suhtlejatel võivad mingi eesmärgi saavutamiseks olla peened, keerukad ja kaugeleulatuvad strateegiad, aga nad saavad neid rakendada ainult väga osaliselt. Põhjuseks on asjaolu, et dialoogi püsimiseks tuleb kuulajal igal juhul reageerida partneri eelnevale kõnevoorule. Kui ta seda ei tee, siis dialoog katkeb, kas ajutiselt või lõplikult. Aga partneri eelnevale voorule reageerimiseks tuleb teha tihti hoopis midagi muud kui enda kaugele kavandatud strateegia jaoks vaja.

Kolmas. Dialoog on pinnal lineaarne eri inimeste kõnevoorude järgnevus, aga seesmiselt mittelineaarne kooslus, mis koosneb suhtlusjärjenditest (ingl sequence). Järjend on eri dialoogides korduv suhtlustegevuste komplekt. Keskne järjenditüüp suulises dialoogis on naabruspaar (ingl adjacency pair), mis koosneb minimaalselt kahest omavahel tihedalt seotud kõnevoorust (nt küsimus-vastus) ja mida suhtlejad võivad järjendi eri positsioonides laiendada (nt küsides soovi esitajalt enne vastamist vastamiseks vajalikku lisainfot).

Neljas. Vestlus on protsess. Kõnevoor on alati protsess, lause on protsess ja iga sõnagi on protsess. Spontaanne suuline suhtlus teeb selle protsessi avalikuks. Kõnelemine toob samal ajal kuuldavale nii lause ehk soovitud tulemuse kui ka sellesama lause moodustamise protsessi.

Viies. Iga keelendi valikut mõjutab talle eelnev keeleline kontekst ning keelend ise mõjutab omakorda järgnevat üksust, muutes sellega ühtlasi konteksti. Keskne motivaator keelelise vormi valimiseks on see, millist suhtlustegevust vastav keelend sooritab ja millises suhtlusjärjendi positsioonis teda kasutatakse. Erinevate suhtlustegevuste tarvis on aja jooksul kujunenud omad keelelised mallid, mida kõnelejad tõlgendavad suhtlusnormidena. Nii valivad suhtlejad näiteks vastavalt suhtlusülesandele üldküsimuse moodustamise eri variante (kas-küsimus, vä-küsimus, jutustav lause jm). Normide järgimine ei ole suhtlejale kohustuslik, aga normi rikkumist vormistatakse alati normist erinevalt ja tajutakse (nt küsimus eeldab vastust, kui seda ei tule, siis peame ootava pausi, küsime uuesti või anname muul moel märku, et midagi on puudu).

Kuues. Suhtluses on alati vigu, häireid, mittemõistmisi, mittekuulmisi jne. Viga, laiemalt võttes probleem, on dialoogi olemuslik osa. Selle ületamiseks on suhtlusesse sisse ehitatud parandusmehhanism ehk vahendite ja normide komplekt probleemide lahendamiseks.

Kuidas vestlusanalüütik tegutseb? Vestlusanalüüs on põhiolemuselt analüütiline (mitte intuitiivne) ja üsna tugevate väliste piirangutega meetod. Toon siin välja kolm olulist piirajat.

Esiteks. Vestlusanalüüs on alt-üles analüüs. See ei alusta teksti üldise idee, mõtte vms otsimisest, vaid konkreetsetest tekstilõikudest. Sellega seostub arusaam, et uurija ei tohiks püstitada hüpoteese ette, vaid peaks minema teksti sisse, otsima sealt korduvaid mustreid või lihtsalt huvitavaid kohti ja analüüsima neid „puhta lehena”. Muidugi tiksub igal analüüsijal kuklas mingi varasem teadmine, kuid oluline on seda mitte piiravaks lähtekohaks võtta, vaid läheneda tekstile avatud meelega.

Teiseks. Vestlusanalüüsi lähtekohaks on arusaam, et tegelikus elus analüüsivad suhtlejad kogu aeg enda ja partneri suhtlustegevusi ning keelt. Seega 
ei ole keele kasutamine üksiku kõneleja tehtud valik, vaid koostöö partneriga. Kuulaja voor toetub sellele, kuidas ta analüüsib kõneleja eelnevat vooru. Kui ta analüüsib lause „Kas mina ei olegi inimene?” küsimuseks, siis ta reageerib ühel viisil, kui aga seisukohavõtuks 'mina olen ka inimene', siis teisel viisil. Sellest tõukub vestlusanalüüsi keskne uurimisvõte: järgneva vooru kontrollimise protseduur (ingl next-turn proof procedure), mille puhul uurija analüüsib kõnevooru esmajoones sellele järgneva ja eelneva vooru suhtlustegevuste ja keelekasutuse abil. Sedasi vaatab uurija vestlust kõrvalt nagu osaleja, mitte ülalt, uurija positsioonilt. Ühtlasi on väga oluline mitte „ronida” kõnelejale pähe, vaid toetuda tõlgendamisel maksimaalselt sellele, mis on tekstis.

Kolmandaks. Vestlusanalüüs ei tuleta inimeste keelelist käitumist väliselt ettemääratud parameetritest (inimese sotsiaalsetest omadustest, suhtlussituatsioonist vms), vaid lähtub sellest, et sõnade lõplik tähendus ja roll pannakse paika just antud suhtlusaktis, kõneleja ja kuulaja koostöös. See ei tähenda väliste parameetrite kõrvalejätmist. Välise konteksti loovad suhtlejad, kuid see tuleb esile just niipalju, kui suhtlejad seda paista lasevad. ${ }^{7}$

Nüüd tuleb olulisim küsimus: mida see meile annab? Kas see analüüs annab midagi juurde sellele, mida me saame teada ilma vestlusanalüüsita? Annab. Ta viib meid sügavale dialoogi sisse, sõnade taha, annab sissevaate dialoogi sünniprotsessi.

Aga kohe järgneb teine küsimus. Kas see suulise dialoogi analüüsi meetod sobib üldse kirjaliku teksti ja kirjandusteksti tarvis? Kas väljamõeldud tegelased tegutsevad keeleliselt samamoodi nagu elusad inimesed? Jne. Minu vastus on jah. Ma olen kirjandusteose vestlusanalüütilist mikroanalüüsi varem proovinud (Hennoste 2004, 2005, 2012). Ja olen koos kolleegidega uurinud ka laiemat korpust, nimelt üldküsimuse funktsioonide ja vormi seost kirjalikus eesti keeles. See analüüs näitas, et kirjanike loodud tegelased kasutavad üldküsimusi just samal viisil nagu suulise argidialoogi pidajad (Hennoste jt 2016). ${ }^{8}$

\section{Ühe näite analüüs: Kiir ja Toots suhtlemas}

Tuleme tagasi loo alguse juurde, kus Toots ja Kiir suhtlesid.

„Noh,” ütleb ta [Kiir], „kudas te... sa ka siia saite. Teid... sind... teid pole peale kooliaega enam näha olnud. Olite kõik aeg Venemaal?"

„Venemaal ikke,” vastab Toots, paberossikarpi taskust võttes. „Teeme suitsu!” „Eei!” vastab Aadniel ja tõmbab pea õlgade vahele. „Mina ei suitseta. Pole veel õppinud."

Kirjanduslik analüüs ütles meile, et Kiir sattus segadusse. Kindlasti on see nii. Aga seda saanuks edasi anda ka muul moel. Miks Luts valib sina ja

${ }^{7}$ Kui vaatame sellele lähenemisele tähelepanelikult otsa, siis leiame neis põhimõtetes mitmeid sarnasusi sellega, mida pidas oluliseks uuskriitiline lähilugemine. Samuti on kerge näha analoogiaid nt lugejakeskse analüüsiga. Veidi kõrvale ja üldisemaks minnes leiab paralleele Mihhail Bahtini dialoogilise sõna ideedega, nt artiklis „Kõnežanride probleem” (Bahtin 1987). Samas on selged erinevused nt XX sajandi alguse tekstianalüüsiga, mis alustas intuitiivselt ja otsis kõigepealt teksti põhilist ideed vms. Ja vestlusanalüüsi eesmärk ei ole kindlasti tekstimõnu.

${ }^{8}$ Vt ka artikleid kogumikus „Dialogi kaunokirjallisuudessa” (Koivisto, Nykänen 2013). 
teie? Tegelikult on see üks sotsiolingvistika klassikaline probleem: kes kõneleb kellega ja mis tingimustel sina. Siinses situatsioonis lähevad risti kaks mõjurit: kunagine koolivendlus ja sina ning nüüdne erinev sotsiaalne positsioon (külarätsep ja mõisavalitseja), mis nõuaks teie kasutamist. ${ }^{9}$ Nii toob Luts kahe lausega esile oma ajastu sotsiaalsed hierarhiad ja neile vastavad suhtlusmallid Eesti alevikus/külas aastal 1912. Aga seegi oli vaid pealmine kiht. Vaatame, mida teeb kõneleja Kiir.

Kiir alustab oma lauset partikliga noh, mis on suulises eesti keeles kõige tavalisem järjeotsimise/takerdumise partikkel. Selle järel algab küsimus, milles Tootsi märgitakse teie-vormiga, siis tuleb otsimispaus ja sina. Paneme aga tähele, et Kiir jääb sel hetkel sina juurde. Seda näitab fakt, et ta jätkab kohe oma lauset. Aga enne öeldist, mis nõuab ainsuse/mitmuse valikut, muudab ta uuesti vormi ja kasutab öeldist mitmuses. See muudatus on tehtud sujuvalt, aga Luts toob selle esile. Parandusi välja jättes oleks tulemuseks lause „Kuidas sa ka siia saite.” Selle järel alustab Kiir uut lauset, jätkates teie'ga, siis liigub sina peale ja uuesti tagasi teie peale. Alles oma järgmises lauses teeb ta lõpliku otsuse ja kasutab mitmuslikku vormi olite. Lisaks, vaadates kirjaniku ülipeent keelemängu, võib väga vabalt oletada, et ka saatelause koht pole juhuslik. See katkestab alustatud lause ning mõjub veel ühe probleemile osutava pausina.

Vaatame edasi. Kuidas vormistab Kiir oma küsimuse? Üldküsimused jagunevad kaheks (vt Hennoste jt 2016). Põhiosa neist on sellised, milles kõneleja pakub mingi hüpoteesi, arusaama, teadmise ja ootab sellele kinnitust. Harvemini küsitakse üldküsimuste abil ka sellist infot, mida küsija üldse ei tea. Kummagi variandi jaoks on omad vahendid. Infoküsimuse vormistamise põhivahend on eesti keeles kas, kinnitusküsimusel jutustav lause, partikkel jah küsimuse lõpus jms. Kiire küsimus on lause, mille algusest oleks nagu grammatiline alus ära jäetud. See on üks üldküsimuse moodustamise harv võte, mille puhul pole üheselt selge, kas kõneleja ei tea asjast midagi või pakub välja hüpoteesi, millele ta kinnitust ootab. Lihtsalt öeldes: see küsimuse vorm on oma rollilt ebamäärane. Ja see on oluline. Kui Kiir kasutaks kas-küsimust, näitaks ta üheselt, et ei tea Tootsi vahepealsest elukohast midagi. Kui ta kasutaks nt jah-küsimust, siis ta osutaks üsna suurt teadmist. Aga seda tal ilmselt ei ole. Valitud vorm lubab jääda ebamääraseks.

Toots ei vasta lihtsalt: „Jah.” Ta vastab: „Venemaal ikke.” Mida märgib sõna $i k k e$ ? See sõna vastuses tähendab sama kui 'muidugi, loomulikult'. Koos sõnaga Venemaal tähendab vastus umbes 'kus siis veel'. Teisisõnu, Toots tõstab välja, et asi peaks olema niigi selge, küsimus polnud küsimist väärt. Aga see vastus ütleb lisaks midagi väga olulist Kiire küsimuse kohta. Nimelt seda, et Toots jääb rahule Kiire valitud teie-vormiga. Seda tõestab asjaolu, et ta ei tõsta Kiire valikut oma kõnevoorus probleemiks (ei ütle näiteks „Miks sa teietad?" vms). Lisakinnituse leiame muuseas kümmekond lehekülge hiljem. Siis tuuakse Tootsi sisemõtete seas välja fakt, et talle ei meeldi koolivenna vahepealne üleminek sina peale.

${ }^{9}$ On ka teine analüüsivariant. Romaanist ei ole üheselt näha, kas Kiir teab Tootsi mõisavalitseja positsioonist või mitte. Kui ta seda ei tea, siis on takerdumise aluseks info puudumine. Talle pole selge, kas võib jääda koolivennaliku sina juurde või on Tootsi nüüdne sotsiaalne positsioon äkki selline, mis nõuaks teietamist. 
Vastuse järel läheb Toots üle uuele suhtlustegevusele ja pakub Kiirele suitsu. Siin võib arutada, kas selle taga on Tootsi suitsunälg, sisemine ärevus, mis suitsust rahu otsib, või koguni soov kinnitada vana kokkukuuluvust ühise suitsetamisega. Lisame ka siia natuke vestlusanalüüsi.

Mida teeb Kiir? Ta keeldub. Suulise suhtluse naabruspaarid on tihti sellised, milles järelliikmed on valitavad kahest vastandlikust variandist: üks positiivne (oodatud), teine negatiivne (mitteoodatud). Ettepaneku vastuvõtmine on positiivne, tagasilükkamine negatiivne akt. Olulisim on aga see, et need kaks varianti vormistatakse suhtluses süstemaatiliselt erinevalt. Kiire tekst on vormistatud just nii, nagu mitteoodatud reaktsiooni suulises vestluses vormistatakse. Ta lükkab oma vastuse edasi (eei venitus) ja lisab seletuse, mille rolliks on esile tuua, et ütleja ei keeldu lihtsalt niisama.

\section{Vestlusanalüüsi laiendamine}

Selle analüüsi peale võib esitada kaks küsimust.

Esimene: kuhu edasi? Vestlusanalüüsi ideoloogia pakub ühte teed: valida sellest dialoogist üks muster või üks tegevuste järjend ja otsida tekstist samasuguseid. Antud juhul võib otsida nt teistest „Suve” dialoogidest kõnelejate takerdumisi, erinevalt vormistatud üldküsimusi või mitteoodatud reaktsioone. Tulemuseks on näidete kollektsioon, mis lubab analüüsida Lutsu dialoogide ehitamist laiemalt ja leida vastus küsimusele, kuidas on tehtud Lutsu dialoog. Sealt edasi võib minna teiste autorite juurde ning võrrelda näiteks Lutsu ja tema kaasaegsete realistide dialoogiehitust jne.

Teine: mida teha monoloogiga? See on tegelikult küsimus, millel on kaks tasandit. Kõigepealt on olemas kirjaniku teksti monoloogilised osad. Sellele lisaks aga on kogu tekst lugeja jaoks tegelikult monoloog. Monoloogiga vestlusanalüüs ei tegele. Aga minu arvates on see meetod hästi üle kantav ka neile tasanditele.

Lugeja on vastuvõtja ning vastuvõtjakeskne lähenemine on vestlusanalüüsi alus. Vastuvõtja on see, kes määrab teksti interpretatsiooni.

Ka lugeja tegutseb nagu suuliselt suhtleja. Ta lähtub primaarsena tekstist endast. Ta analüüsib teksti alt-üles, konkreetsetest sõnadest, lausetest, lõikudest lähtudes. Lugejagi lähtub sellest, et sõnade lõplik tähendus ja roll pannakse paika just antud suhtlusaktis, koostöös kõneleja ja kuulaja vahel.

Tekst on lugedes alati protsess ja interpreteerimine on protsess. Ka lugeja tõlgendab näiteks lauset ja toetub oma loodud tõlgendusele järgmist lauset tõlgendades. Teisisõnu, ka siin toimub lugeja peas next-turn proof procedure, ainult kõnevooru rollis on see osa tekstist, mida lugeja ühekorraga tõlgendab. Kusjuures ta võib ise otsustada, kui pikkadeks tükkideks ta teksti enda jaoks jagab. See võib olla sõna, lause, lõik, kas või häälik. Nii võiksime nimetada seda võtet järgneva tüki kontrollimise protseduuriks (ingl next-item-proof procedure).

Dialoogi terminites võime öelda, et lugeja sekkub oma tõlgendustega kirjutaja vooru nagu suulises kõnes tagasiside andja. Vestluses ütleme ahah, kui kuuleme midagi uut, ning jah, kui oleme nõus. Sama teeme lugedes, enamasti endamisi, aga mõnikord ka poolvaljusti. Tegelikult on kogu lugemine nagu üks suur tagasiside kogum. Ning tekst kui monoloog on lihtsalt üks hiigelpikk ja mitmekomponendiline kõnevoor. 
Veel enam, ka kirjanik vajab tegelikult lugeja pidevaid reaktsioone, kuigi need sõnaliselt pea kunagi temani ei jõua. Kui ta tahab näiteks tulla lagedale üllatava pöördega, siis peab ta lugeja esmalt viltu juhtima. Lugeja ei anna autorile valjusti teada, et ta on läinud sinna, kuhu kirjanik tahtis, aga vaikselt, omaette peab ta seda tegema. Muidu masin ei tööta.

See omakorda toob välja, et ka siin on oluline nähtus viga. Lugeja võib mingit tekstikohta valesti tõlgendada ja hilisema mõistmise valguses ümber tõlgendada (või ka selle juurde jääda). Lugemine on pidev korrektse lugemise ja väärlugemise vaheldumine.

Kokkuvõtteks. Vestlusanalüüsi tulemus on otsekui kubofuturistlik pilt tekstist. Selle kvalitatiivne pool on kubistlik, see vaatab maailma väga lähedalt ja korraga mitmest rakursist. Selle protsessuaalne pool vaatab teksti liikumises nagu futuristlik maal. Ja kui vaja, siis saab lisada juurde kvantitatiivse pildi, vaate ülalt otsekui futuristlikus aeropittura's. Kokkuvõttes on aga nii autor, tema tegelased, lugejad kui ka uurijad osalised suures kubofuturistlikus mängus.

\section{Kirjandus}

B a htin, Mihhail 1987. Kõnežanride probleem. Tlk A. Kabur. - M. Bahtin, Valitud töid. Tallinn: Eesti Raamat, lk 267-284.

B arthes, Roland 1998. Autori surm. Tlk Marek Tamm. - Looming, nr 12, lk 1851-1855.

Biber, Douglas 1988. Variation across Speech and Writing. Cambridge: Cambridge University Press.

Biber, Douglas, Conrad, Susan 2009. Register, Genre, and Style. Cambridge: Cambridge University Press.

Chambers, J. K., Trudgill, Peter 1998. Dialectology. Cambridge: Cambridge University Press.

Hennoste, Tiit 2004. Kõneldud näidend ja suuline keel. - Teater. Muusika. Kino, nr 5, lk 39-44.

Hennoste, Tiit 2005. Kõne kohanemine kirjandusega. - Kohanevad tekstid. Koost, toim Virve Sarapik, Maie Kalda. Eesti Kirjandusmuuseum, Eesti kultuuriloo ja folkloristika keskus, Tartu Ülikooli eesti kirjanduse õppetool. Tartu: Eesti Kirjandusmuuseum, lk 25-42.

Hennoste, Tiit 2012. Elu ja kirjanduse piiril. Suhtlemine Oskar Lutsu „Kevades". - Looming, nr 11, lk 1621-1631.

He n n o s te, Tiit 2014. Ümbertegemine. - Eva Liina Asu-Garcia, Mati Erelt, Külli Habicht, Tiit Hennoste, Reet Kasik, Helle Metslang, Andriela Rääbis, Pire Teras, Annika Viht, Eesti keele kirjeldava grammatika prospekt. Tartu: Tartu Ülikool, lk 70-83.

Hennoste, Tiit 2016. Eesti kirjanduslik avangard 20. sajandi algul. Hüpped modernismi poole I. (Heuremata.) Tallinn-Tartu: Tartu Ülikooli Kirjastus.

Hennoste, Tiit, Metslang, Helle, Habicht, Külli, Jürine, Anni, La a nes o o, Kirsi, Og r e n, David 2016. Üldküsimuse vorm ja funktsioonid läbi nelja sajandi ja kuue tekstiliigi. - Emakeele Seltsi aastaraamat 61 (2015). Tallinn: Teaduste Akadeemia Kirjastus, lk 80-109.

Hi i r, Erni 1975. Mässulaulud. Valik võitlusluulet 1918-1930. Tallinn: Eesti Raamat. 
Jak obs o n, Roman 2012 [1960]. Lingvistika ja poeetika. Tlk Neeme Lopp, Arne Merilai. - Akadeemia, nr 10, lk 1731-1773.

Jockers, Matthew L. 2013. Macroanalysis. Digital Methods and Literary History. University of Illinois Press.

Ka sik, Reet 2011. Stahli mantlipärijad. Eesti keele uurimise lugu. Tartu: Tartu Ülikooli Kirjastus.

Koivisto, Aino, Nykänen, Elise (toim) 2013. Dialogi kaunokirjallisuudessa.

(Tietolipas 242.) Helsinki: Suomalaisen Kirjallisuuden Seura.

Li iv, Toomas 2003. Luuletused 1968-2002. Tallinn: Tuum.

Luts, Oskar 1987. Suvi. Tallinn: Eesti Raamat.

Malpas, Simon, W ake, Paul (koost) 2015. Kriitilise teooria käsiraamat. Tlk Marilin Lips. Tallinn: Tallinna Ülikooli Kirjastus.

Mor etti, Franco 2013. Distant Reading. London-New York: Verso.

R o bins, Robert H. 1990. A Short History of Linguistics. Third edition. LondonNew York: Longman.

Seld en, Raman, Widd ow s on, Peter, Brooker, Peter 2005. A Reader's Guide to Contemporary Literary Theory. Fifth edition. London etc: Pearson.

Sidnell, Jack 2013. Basic conversation analytic methods. - The Handbook of Conversation Analysis. Toim J. Sidnell, Tanya Stivers. Oxford: Wiley \& Blackwell, lk 77-99.

Terentjev, Igor 2014. 17 tyhjänpäiväistä työkalua. - Venäläisen avantgarden manifestit. Toim Tomi Huttunen. Helsinki: Osuuskunta Poesia, lk 103-126.

Wellek, René 1991. History of Modern Literary Criticism: 1750-1950. Volume

7. German, Russian, and Eastern European Criticism, 1900-1950. New Haven: Yale University Press.

\section{Liberation of philology from Excel: The programme of a Cubo-Futurist Neo-Philology}

Keywords: linguistics, literary studies, conversation analysis, analysis of literary dialogue

The first half of the article provides a survey of the main directions of the $20^{\text {th }}$ century divergence of linguistics and literary studies.

In the first half of the $20^{\text {th }}$ century, mainstream studies took a synchronic approach to language and literature, addressing language as a system and focusing on individual literary works, their language and style.

The mid-century brought a great divergence. Linguistics changed to embrace functionalism, empiricism and objective analysis. Literary studies, however, fell for the postmodern critical theory, which basically questions the quest for objective knowledge. Literary studies focused on modernism and modernist language, leaving linguistics aside. For linguistics, the new norm was corpus-based approach and quantitative analysis. Most of the empirical literary studies of the second half of the century remain classifiable as qualitative micro-analysis.

New changes emerged in the 1990s. In literary studies, close reading found a rival called distant reading, while quantitative computer analysis of large corpora established itself beside the traditional qualitative analysis. Linguistics turned to qualitative microanalysis of communication, especially addressing spontaneous dialogue, while conversation analysis was used as the principal method. 
The second part of the article offers a suggestion how studies of language and literature could be brought together again. The starting point is a real text as a synchronic and empirical object of research. The primary method is qualitative analysis to which the quantitative approach has a subsidiary role. Conversation analysis is suggested as the method to analyse a literary work.

There follows a survey of the core concepts (social action, sequence, adjacency pair, processuality, repair) and principles (bottom-up analysis, next-turn proof procedure, analysis of inner context) of conversation analysis. As a practical example, I will use conversation analysis on a fragment of a novel by Oskar Luts. My final postulate is that conversation analysis can be applied to whole literary texts entering a dialogue with the reader.

Tiit Hennoste (b. 1953), PhD, University of Tartu, Institute of Estonian and General Linguistics, Laboratory of Spoken and Computer Mediated Communication, Senior Researcher; tiit.hennoste@ut.ee 